\title{
Időjárás elörejelzö mérőállomás Raspberry Pi 3 Raspbian Linux alapon
}

\author{
Horváth Milán \\ Informatikai Kar \\ Debreceni Egyetem, Müszaki Kar \\ Debrecen, Magyarország \\ horvathmilan96@gmail.com
}

\author{
Erdei Timotei István \\ Mechatronikai Tanszék \\ Debreceni Egyetem, Müszaki Kar \\ Debrecen, Magyarország \\ timoteierdei@eng.unideb.hu
}

\begin{abstract}
Absztrakt- A Raspberry $\mathbf{P i}$ megjelenésével rengeteg testreszabható projekt elkészülhet, amelyek különféle szenzorokat illetve egyéb kompatibilis eszközöket használnak. A Raspberry Pi 3 sokoldalúságát kihasználva ebben a projektben egy hőmérséklet- és páratartalom érzékelő segítségével automatizálódik a LED-ek megvilágításának egy része, míg a másik része a python programozás előnyeit kihasználva, a napi maximum szerint választja meg színét. A különböző hőmérséklet intervallumok különböző színeket eredményeznek. A LED-ek „láthatatlanságát” egy fából készített felhő alak fedi el, melynek formája utal a használati területre, illetve dizájn szempontjából is sokkal esztétikusabb.
\end{abstract}

Kulcsszavak-Höérzékelö, Raspberry, SSH, ütemezés, digitális LED, python

\section{BEVEZETŐ}

A Raspberry Pi első sorban az elektronika és a programozás összefüzését elősegítő oktatási és hobbi célokra tervezett eszköz. Egyik nagy előnye az alacsony fogyasztása, illetve az ingyenesen telepíthetö rendszerek. A Raspberry olyan ingyenes Linux disztribúciókat képes futtatni, mint például a Raspbian [1] vagy az Ubuntu MATE [2]. Ezek a rendszerek grafikus felületü operációs rendszerek, amelyek rengeteg alapvető alkalmazással és optimalizációval rendelkeznek.

A telepített rendszerek egyik nagy elönye, hogy mivel ezek ingyenes és nyílt operációs rendszerek, ezért nem szükséges a különféle jogosultságokkal foglalkozni, ugyanis a telepített rendszert könnyedén használhatja a felhasználó rendszergazdaként, amelyet a Raspbian úgynevezett superuser-ként hív. Ahhoz, hogy programokat, utasítások superuser-ként hajtson végre a rendszer, a futtatandó utasítás elött a ,, sudo” kapcsolót kell alkalmazni.

A Raspberry Pi 3-ra egy Raspbian nevü operációs rendszer kerül, melynek segítségével könnyedén futtathatjuk a kívánt programot, illetve nagyon egyszerüen tudjuk azt automatizálni, esetleg az eredményeket eltárolni későbbi, statisztikai kimutatásokhoz.

Ennek a projektnek a tervezési és létrehozási folyamatához a Debreceni Egyetem, Információtechnológiai Tanszék laborja biztosított helyet. A kutatás/fejlesztésnek a Debreceni Egyetem adott otthont [8].

\section{TERVEZÉSI FÁZIS}

A projekt tervezésének első szempontja a digitális LED címezhetőségének a kihasználása, így több területet is figyelembe lehet venni a hömérsékleti adatok felhasználóval való közlésekor.

Az első szempont szerint az úgymond belső hőmérséklet, vagy aktuális hőmérséklet mérése volt a cél, melynek során az adott helyiség hömérsékleti adatait egy DHT 11 hömérsékletés páratartalom érzékelő modul segítségével kapjuk meg.

A második szempont a külső napi hőmérsékleti maximum, illetve minimum meghatározás volt a cél, melyeket a Python programozási nyelv segítségével könnyen megkaphatunk.

A digitális LED segítségével mind a két értéket ki lehet „közvetíteni” a fényekre. A terv szerint a 12 LED-ből az első 6 az aktuális, vagy benti hőmérséklet szerint fogja választani színét, a második 6 LED pedig a külső, napi maximum hőmérséklet szerint.

A felhő alakja méretének megtervezésekor ezt figyelembe véve készült el a minta, ami alapján létrejött a LED-eket eltakaró dizájn doboz. Méreteit tekintve: $10 \mathrm{~cm}$ x $15 \mathrm{~cm} \mathrm{x} 1 \mathrm{~cm}$

Az elkészült minta az 1. ábrán látható.

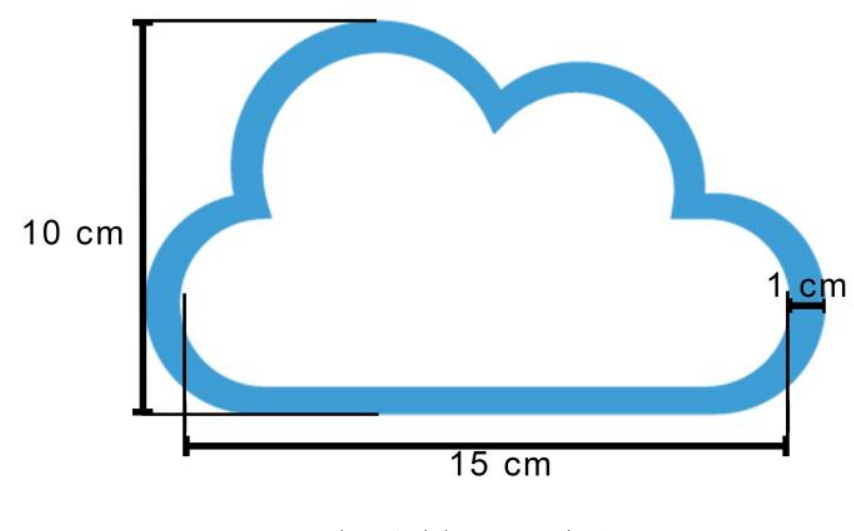

1. ábra $\mathrm{A}$ doboz méreteinek terve 


\section{A FELHÖ FELÉPÍTÉSE}

A doboz elkészítésénél figyelembe véve a LED szalag szélességét, ami $1 \mathrm{~cm}$, több darabra volt szükség, ugyanis 0,7 cm vastagságú fa lapból kerültek kivágásra az elemek.

A 4 külön egység elkészítése után ezek összeillesztése, illetve összeragasztása volt a következő lépés. 3 rész összeragasztása után a LED szalag elhelyezése következett, melynél figyelembe véve a külön színeződést, 6-6 LED külön „tartományba" került, így megelőzve az esetleges nagy színkeveredést, illetve a 3 csatlakozási pontnak egy $0,7 \mathrm{~cm}$ átmérőjü furat készült, melyeken egy 3 erü kábel csatlakozik a LED szalagra.

A LED szalag elhelyezése után annak meggyőződése érdekében, hogy minden LED a tervezett szempontok szerint világít, illetve, hogy a hőmérsékleti adatoknak megfelelöen választja meg a szín kombinációkat a program tesztelésre került. A tesztelés során a kapott hőmérséklet, illetve a napi maximum megállapítása után a program a helyes értékeket kiküldve, a hozzá tartozó színekben világította meg az első 6, illetve a második 6 LEDet, ahogy a 2. ábrán látható.

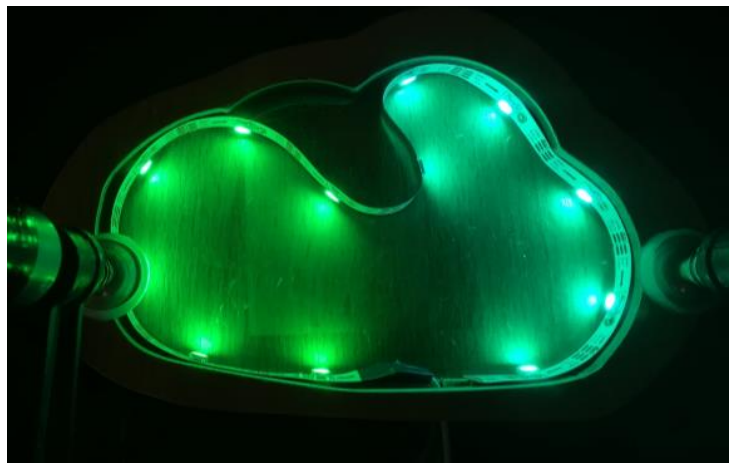

2. ábra A program tesztelése az elhelyezett LED szalaggal

Ahhoz, hogy a LED szalag ne legyen látható, olyan megoldásra volt szükség, amelynél a fények átszürődnek. A legegyszerübb megoldásnak a pauszpapír tünt, amely a felhő alakjára szabva, majd az utolsó elemet rá helyezve került végső állapotába. A száradás után egy újabb tesztre került sor, amely során a már kész állapotban lévő felhő lett megvilágítva az adott hőmérsékleti adatok szerint, illetve az esztétikusabb kinézet érdekében az egyes elemek összecsiszolásra kerültek, amely az 3. ábrán látható.

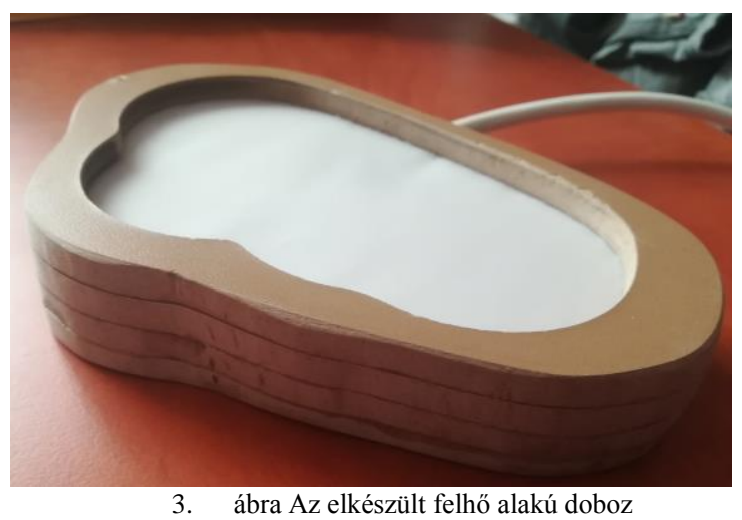

Ez után következhetett a program automatizált és dokumentált működésének ellenörzése, amely során létrejött dokumentációkból, értékekből könnyen statisztikai adatokat lehet készíteni.

\section{MEGÉPÍTETT ÁRAMKÖR}

Az áramkör Fritzing-ben [3] került megtervezésre, aminek fó része a Raspberry Pi 3 model B, amely a DHT 11 Hőmérséklet- és páratartalom szenzort, illetve a WS2812 típusú LED szalagot köti össze, illetve vezérli ezek működését. A Raspberry a megírt Python program segítségével a DHT 11-en keresztül megkapja az aktuális helyiségben lévő hőmérsékletet, és egy úttal a napi minimum és maximum hőmérsékletet is, majd ez alapján választja ki, hogy melyik színnel világítsa meg a felhőt. Az 4. ábrán látható a megtervezett áramkör fizikai kapcsolása.

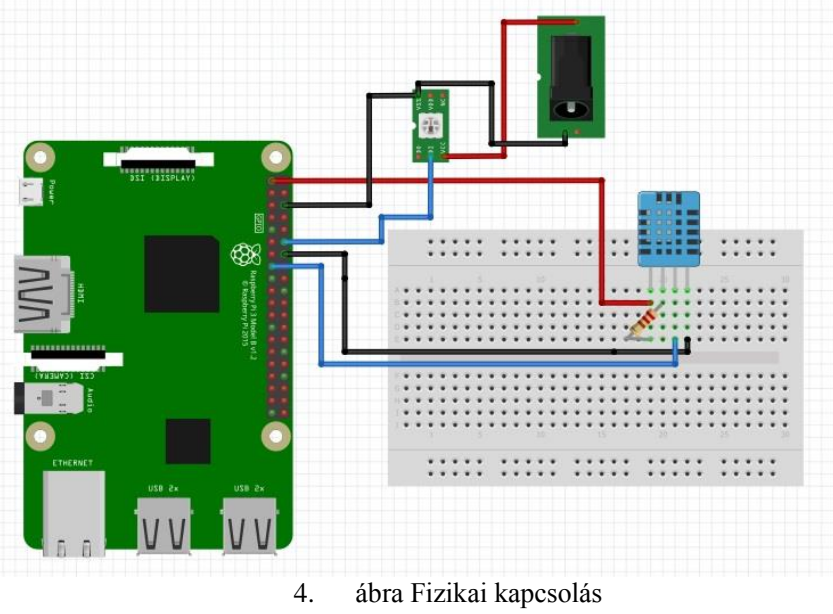

A DHT 11 szenzor egy 4 lábas verzió, amely az alábbi lábkiosztással rendelkezik:
1. $\operatorname{Vcc}(+)$
2. Signal
3. Not Used
4. Ground (-)

A helyes bekötéshez az 1-es (Vcc), illetve 2-es (Signal) láb közé egy 4,7K-s ellenállás szükséges, illetve egy fontos része a kapcsolásnak, hogy a szenzor, a LED szalag, illetve a táp is közös földdel rendelkezzen.

A szenzor kapacitív páratartalom mérővel és termisztorral rendelkezik, nincs szükség analóg portra a müködéséhez. 2 másodpercenként van lehetőség egy új mérésre. 3.3-5V közötti tápfeszültség javasolt az üzemeltetéséhez. A környezeti hőmérséklet intervalluma 0-50 Celsius közötti, -+2 fok pontossággal.

A relatív páratartalom 20-95\% közötti mérését 5\% pontossággal képes elvégezni az eszköz.

A WS2812 típusú címezhető LED kihasználtságának érdekében került a programba az a funkció, amely a napi 
hőmérsékleteket meghatározza, ugyanis így érvényesül a címezhetöség elve.

A LED szalag és a Raspberry összekapcsolásánál nincs szükség tranzisztorra, illetve ellenállásra a hagyományos típusú SMD 5050 LED szalaghoz képest.

A WS2812 típusú LED helyes lábkiosztása, illetve paraméterei az 1. táblázatban láthatóak, amely segítségével könnyedén megérthető a digitális LED müködésének egyszerüsége.

\begin{tabular}{|l|l|l|}
\multicolumn{1}{l}{ 1. TÁBLÁZAT } & \multicolumn{1}{c|}{ WS2812 LÁBKIOSZTÁS } \\
\hline Láb & Név & Funkció \\
\hline 1 & DO & Adat kimenet \\
\hline 2 & DI & Adat bemenet \\
\hline 3 & VCC & Vezérlö tápfeszültség \\
\hline 4 & NC & Nem használt \\
\hline 5 & VDD & LED tépfeszültsége \\
\hline 6 & VSS & Közös pont (GND) \\
\hline
\end{tabular}

A táblázatba foglalt adatok, illetve lábkiosztás megértéséhez a 5. ábrán látható felépítés van segítségül.

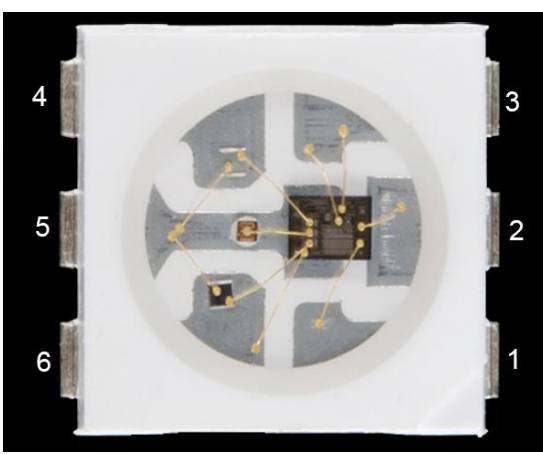

5. ábra WS2812 LED felépítése

\section{TESZTELÉS}

A folyamat első lépése a DHT 11 tesztelése volt, mely a Raspberry-hez csatlakoztatva zajlott. A legegyszerübb tesztelése a szenzornak, hogy valós értékeket kapunk-e, hogy futtatjuk a programot úgy, hogy a szenzor egy olyan helyen van ahol nagyjából tudjuk a hőmérsékletet. Ebben a projektben fontos a folyamatos valós információ, ezért a szenzor úgy került tesztelésre, hogy egy olyan helyen ahol volt információ a hőmérsékletröl, folyamatos programfuttatás történt. Ez nem manuálisan történt, hanem a Raspbian rendszeren lévő CRON [7] segítségével.

A CRON egy olyan ,alkalmazás”, amely segítségével ütemezhetjük a programjaink futásait, megadhatjuk, hogy hány percenként, óránként, naponta, havonta fusson le a programunk. A tesztelési folyamat során ezt kihasználva történt a programfuttatás.

A CRON-t lehetőség van grafikus felülettel, illetve parancssorból használni. A grafikus felület telepítéséhez egy parancsablak megnyitása után a következő utasítást kell megadnunk a Raspbiannak: „sudo apt-get install gnomeschedule”. A telepítés befejeztével a program ScheduLED Tasks néven érhető el a rendszeren.
A nem grafikus felületü CRON-t a „crontab $-e$, paranccsal hívhatjuk meg a Raspbian termináljában. A CRON első megnyitásakor a rendszer 3 szövegszerkesztési lehetőséget ajánl fel, amely közül a nano-t érdemes választani. Ezután megadhatjuk mely programot szeretnék futtatni és mikor, illetve akár több program együttes futtatására is lehetőség van.

Ebben az esetben a megírt program futtatása történt minden 5. percben, illetve az aktuális dátum és időpont került hozzáfüzésre.

A tesztelés során az alábbi parancs került a CRON-ba:

$* / 5 * * * *$ sudo date $>$ result.txt

$* / 5 * * * *$ sudo python /home/pi/AdafruitDHT.py 1122 > result.txt

Az alap utasítás $5 *$ karakterrel kezdődik majd az utasítás következik az alábbi formában: $* * * * *$ parancs

- $\quad$ Elsö * karakter: perc (0-59)

- Második * karakter: óra (0-23)

- Harmadik * karakter: hónap adott napja (1-31)

- Negyedik * karakter: hónap (1-12)

- Ötödik * karakter: a hét napja (0-7)

Az első parancs 5 percenként fut le, rendszergazdai jogosultsággal és az aktuális dátumot füzi hozzá a result.txt tartalmához, így hitelesítve az időpontot.

A második parancs szintén 5 percenként fut le, rendszergazdai jogosultsággal és a megírt programot futtatja le a szükséges parancssori argumentumokkal, majd a kimenetet hozzáfüzi a result.txt tartalmához, így megkapva a hőmérsékleti adatokat, ahogy a 6 . ábrán látható.

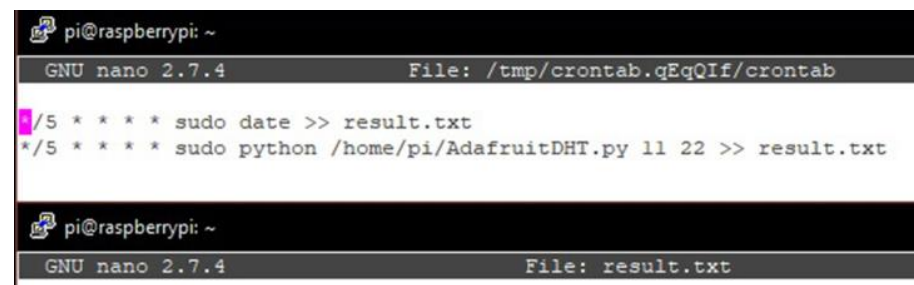

Thu Apr 5 23:10:01 CEST 2018

Temperature: 28.0 celsius Humidity: $24.0 \%$

Todays high is: 20 celsius

Todays low is: 8 celsius

Thu Apr 5 23:15:01 CEST 2018

Temperature: 28.0 celsius Humidity: $23.0 \%$

Todays high is: 20 celsius

Todays low is: 8 celsius

Thu Apr 5 23:20:01 CEST 2018

Temperature: 29.0 celsius Humidity: 22.0 응

Todays high is: 20 celsius

Todays low is: 8 celsius

6. ábra A CRON eredményei

A projekt másik fontos részének, a LED szalagnak a tesztelése egy mintaprogram segítségével történt, amely során minden LED a programnak megírt utasításoknak megfelelően világított, müködött.

\section{AZ ESZKÖZ MÜKÖDÉSI ELVE, PROGRAM MÜKÖDÉSE}

Ebben a részben megismerkedünk az eszköz müködési elvével, és a Raspberry-n futtatott program müködési elvével.

A Raspberry előnye, hogy nem feltétlen szükséges képernyő, illetve beviteli eszközök használata. A hálózatunkra 
csatlakozva könnyen kapcsolatot tudunk teremteni számítógépünk és a Raspberry között.

Ehhez egy úgynevezett PuTTY [4] program szükséges, amely segítségével SSH-n keresztül, IP cím megadásával csatlakozni tudunk egy terminálon keresztül a Raspbian rendszerünkhöz, így könnyedén kezelhető az eszköz, illetve módosítható a program.

A csatlakozás folyamán szükség lesz egy felhasználói névre, amely a „pi” karaktersorozat, illetve első csatlakozáskor az alapértelmezett jelszót kell megadni, amely a „raspberry” karaktersorozat. Első csatlakozás után érdemes a jelszót megváltoztatni biztonsági okokból. Ezt egy parancsablak megnyitása után a ,passwd” kulcsszó megadása után tehetjük meg, amely beírása után meg kell adnunk az aktuális, jelen esetben az alapértelmezett jelszót, majd beírható az új jelszó, illetve egy ,,enter” lenyomásával megerősíthető.

Az alap koncepció a kinti hömérséklet szerinti megvilágítás volt, mely később ki lett egészítve a már említett DHT 11-es szenzorral.

A program futtatásakor a szoftver „lekéri” a napi maximum és minimum hőmérsékletet a yahoo segítségével, majd a DHT 11 segítségével megállapítja az aktuális hőmérsékletet.

Ezután ezen adatok kiértékelése következik, amely során az aktuális értékhez hozzárendeli az adott RGB színkódot a program. A szoftver müködésének folyamatát a 7. ábra mutatja, amely UMLet [5] segítségével készült.

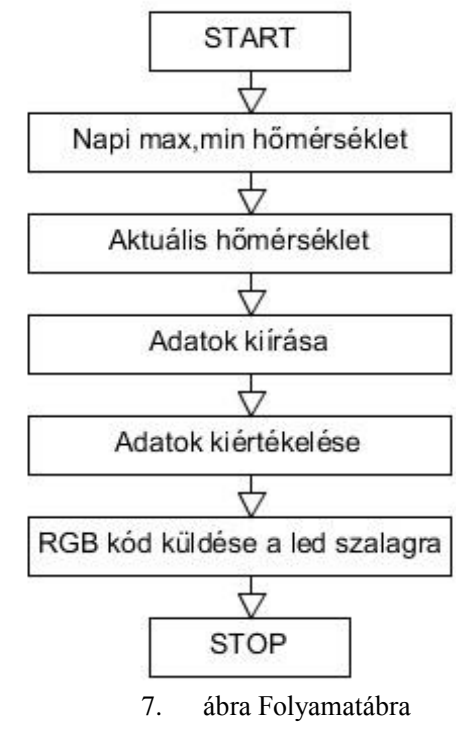

A program helyes müködéséhez szükség van az Adafruit_Python_DHT [6] könyvtárra, amely a digitális LEDek programozását könnyítik meg.

Ha esetleg más méretű a doboz vagy kevesebb - több LEDet szeretnénk használni, könnyen testre szabhatjuk programunkat, ugyanis a program elején lévő definíciónál a LED_COUNT változót a 12-es értékről átírva megadhatjuk egyéni LED darab számunkat.

A programon számos egyénre szabható lehetőség van még, ugyanis megadhatjuk azt, hogy melyik várost tekintse tartózkodási helyünknek, illetve azt, hogy Celsiusban vagy Fahrenheitben kapjuk meg a napi értékeket.

A where text="város, wi" utasításnál a város szót kell helyettesítenünk a kívánt várossal, így a programunk az itt megadott helység adatait veszi figyelembe.

A második sorban lévő $u=, c$ " utasításnál a c jelentése a Celsius, ennek elhagyása Fahrenheit formátumot eredményez.

A program két függvénnyel rendelkezik, amelyek felelnek a LED szalagot színeinek megjelenítéséért. Az első függvény - inside - az első 6 db LED megvilágításáért felel az aktuális hőmérséklet függvényében, a programban 0-5 közötti számokkal indexeljük, ugyanis az indexelés 0 -tól kezdődik és nem 1-töl.

A második függvény - outside - az utolsó 6 LED, vagyis a 6 és 11-es indexü LEDeket világítja meg a napi maximum hőmérséklet szerint.

A függvényeket tartalmazó utasításokat az Adafruit könyvtár tartalmazza. A függvényekben szereplő utasítások és funkcióik:

$>$ setPixelColor(uint16_t $n$, uint32_t c): Adott sorszámú pixel színmegadása színkóddal

$>$ Color(uint8_t $r$, uint8_t $g$, uint8_t $b$ ): Színkód származtatása RGB komponensekböl

$>$ time.sleep(wait_ms/500.0): A LEDek közötti színváltás idejének megadása

$>\quad$ setBrightness(uint8_t $t \quad b)$ : Fényerösség beállítása (ez csak egyszer hívható meg)

$>$ show(void): Megjelenítés az előzőleg beállított adatokkal

Miután programunk rendelkezik a megfelelő hőmérsékleti adatokkal, következő lépésként kiértékeli azokat. if elágazások segítségével történik a kiértékelés, amely létrejön mind az aktuális, mind a napi maximum hőmérséklet színénél. Miután az elágazások között a program megtalálta az értéknek megfelelö intervallumot, beállítja a LED szalag adott LEDjeit a megfelelö, intervallumhoz hozzárendelt színekre. A meghatározott színeket a már korábban említett show(void) utasítással kapja meg a LED szalag.

A program megírásakor létrejött egy intervallum táblázat, ami kimutatja, hogy milyen hőmérsékleti értétek között milyen színben kell világítania a LED szalagnak. A színek meghatározása a hőmérséklet szerint történtek, illetve minden szín tesztelésre került, abból a szempontból, hogy a LED szalag képes-e megvilágítani az adott színt, amely az adott hőmérséklethez lett rendelve. A program írása közben meghatározott intervallumok, valamint a LED szalag által támogatott színkódok a 8. ábrán láthatóak. 


\begin{tabular}{|c|c|c|}
\hline temp & color & color code \\
\hline$>40$ & & 25508 \\
\hline [35:39] & & 255700 \\
\hline [30:34] & & 2551610 \\
\hline [25:29] & & 2552340 \\
\hline$[20: 24]$ & & 252550 \\
\hline [15:19] & & 025564 \\
\hline$[10: 14]$ & & 0255149 \\
\hline$[5: 9]$ & & 0255215 \\
\hline$[0: 4]$ & & 0166255 \\
\hline$[-5:-1]$ & & 03255 \\
\hline$[-10:-6]$ & & 10435173 \\
\hline [-15:-11] & & 647102 \\
\hline$<-16$ & & 27343 \\
\hline
\end{tabular}

8. ábra Intervallumok és színkódok

Az intervallumok és a hozzá rendelt színkódok megértését az alábbi táblázat foglalja magába, amely megmutatja, hogy egy véletlenszerü hőmérséklet esetén mely színkódot alkalmazza a program a LED szalagra.

2. TÁBLÁZAT MAGYARÁZAT

\begin{tabular}{|c|c|c|}
\hline Aktuális hőmérséklet & Szín & Színkód \\
\hline $24^{\circ}$ & & R: 25 G: 255 B:0 \\
\hline $36^{\circ}$ & & R: 255 G: 70 B: 0 \\
\hline $2^{\circ}$ & & R: 0 G: 166 B: 255 \\
\hline Napi maximum & & \\
\hline$-5^{\circ}$ & & R: 0 G: 3 B: 255 \\
\hline nagyobb mint $40^{\circ}$ & & R: 255 G: 0 B: 8 \\
\hline $12^{\circ}$ & & R: 0 G: 255 B: 149 \\
\hline
\end{tabular}

A teljes egészében összeszerelt és üzembe helyezett eszköz megfelelően és stabilan müködött. A 9. ábra mutatja az eszköz müködését, megvilágítását kész állapotban.

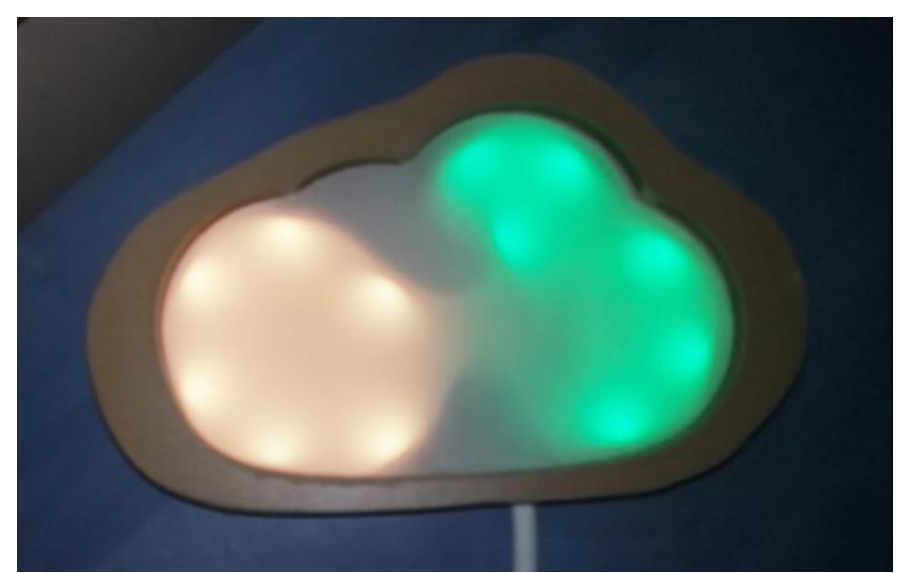

9. ábra Az elkészült projekt

\section{VII. ÖSZEGZÉS}

A projekt összességében a megtervezettek szerint készült el, mind fizikailag, mind elektronikailag.

A Raspberry Pi 3 model B segítségével létrejött az elképzelés és sikeres lett a címezhető LED kihasználtsága. Az eszköz könnyen automatizálható a már említett CRON segítségével, így személyre szabottan lehetséges a program futtatásának időpontja, amelyet használva nincs szükség a program folyamatos manuális futtatására.

Esetleges fejlesztési lehetőség lehet például egy hálózaton több kliens időjárás állomás, vagy olyan helyzetekben, amikor a külső hőmérséklet nem számít, a DHT 11 segítségével bizonyos helyiségekben vagy tároló helyeken hőmérsékleti statisztika készítése, esetleg kritikus helyzetekben (adott helyiség hőmérséklete túl magas, vagy túl alacsony) értesítés küldése hálózaton keresztül a megfelelő személynek.

\section{KÖSZÖNETNYÍLVÁNITÁS}

A publikáció elkészítését az EFOP-3.6.1-16-2016-00022 számú projekt támogatta. A projekt az Európai Unió támogatásával, az Európai Szociális Alap társfinanszírozásával valósult meg. Szeretném köszönetemet nyilvánítani Dr. Godó Zoltánnak az Informatikai Kar Információ Technológia Tanszék adjunktusának a labor rendelkezésre bocsájtását.

\section{HIVATKOZÁSOK}

[1] Raspbian, (2018, Március). [Online]. Available: https://www.raspberrypi.org/downloads/raspbian/

[2] Ubuntu MATE 14.04 LTS, (2014, November 11). [Online]. Available: https://ubuntu-mate.org/blog/ubuntu-mate-trusty-final-release/

[3] fritzing, (2016, Június 2). [Online]. Available: http://fritzing.org/download/

[4] PuTTY, (2017, Június 08). [Online]. Available: https://www.putty.org/

[5] UMLet, (2017). [Online]. Available: http://www.umlet.com/

[6] Adafruit_Python_DHT, (2017, Március 1). [Online]. Available: https://github.com/adafruit/Adafruit_Python_DHT

[7] CRON, (2017, Március 1). [Online]. Available: https://www.rackhost.hu/tudasbazis/webtarhely/cron/

[8] T. I. Erdei, Zs. Molnár, N. C. Obinna, G. Husi, „A Novel Design of an Augmented Reality Based Navigation System \& its Industrial Applications," 15th IMEKO TC10 - Technical Diagnostics in CyberPhysical Era Budapest, Hungary, 6 - 7 June, 2017 - Organised by: MTA SZTAKI - Hungarian Academy of Sciences - Institute for Computer Science and Control. 